
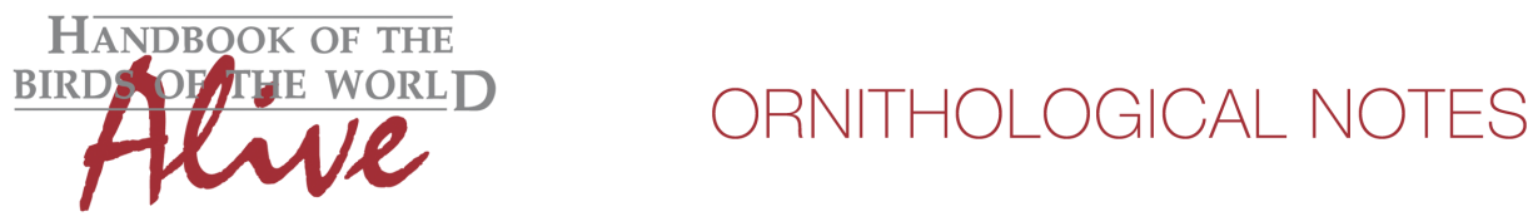

\title{
Notes on the vocalizations of White-eyed Tody-tyrant (Hemitriccus zosterops)
}

Peter Boesman

In the following we briefly analyze and compare voice of the different races of White-eyed Tody-tyrant (Hemitriccus zosterops). We also try to quantify the extent of any vocal differences using the criteria proposed by Tobias et al. (2010), as a support for taxonomic review. We have made use of sound recordings available on-line from Xeno Canto (XC).

As an initial remark, White-eyed Tody-tyrant was split from White-bellied Tody-tyrant $H$. griseipectus presumably based on Cohn-Haft et al. (1997). The East Brazilian race naumburgae was not discussed in this paper, and thus different authors have either placed it as a subspecies of $H$. zosterops (e.g. HBW) or $H$. griseipectus. Voice and presumably also morphology indicate it is best placed in $\underline{H}$. griseipectus.

In what is thus left as $H$. zosterops, there seem to be two vocal groups (Fig. 1), east and west of the Rio Negro.

East of the Rio Negro (= Guianan)

Presumed song is a rattled trill, sometimes preceded by one or a few short "pik" notes (which can also be given alone as a call)(can be heard from Manaus to French Guyana). Measurements $(n=5)$

$\begin{array}{ll}\text { total length } & 0.58-1.44 \mathrm{~s} \\ \text { \# of notes } & 19-38 \\ \text { max. pace* } & 0.02-0.035 \\ \text { av. freq. } & 1600-1850 \mathrm{~Hz} \\ \text { max. note length } & 0.027-0.039 \mathrm{~s}\end{array}$

* pace is measured here as period, duration between 2 consecutive notes

\section{West of the Rio Negro}

Presumed song is a series of notes, sometimes preceded by one or a few short "pik" notes (which can also be given alone as a call)(can be heard in Peru, E Ecuador, SE Colombia, NW Brazil up to the confluence of Rio Negro and Rio Amazon)

Measurements $(n=10)$

total length

$0.70-1.70 \mathrm{~s}$

\# of notes

5-15

max. pace

0.085-0.17

av. freq.

$1910-2300 \mathrm{~Hz}$

max. note length

0.04-0.05s 


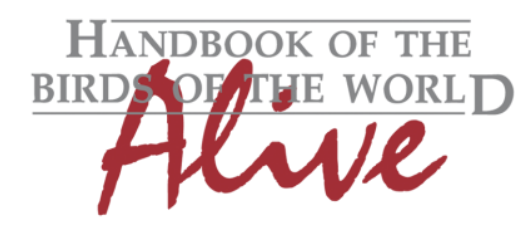

\section{ORNITHOLOGICAL NOTES}
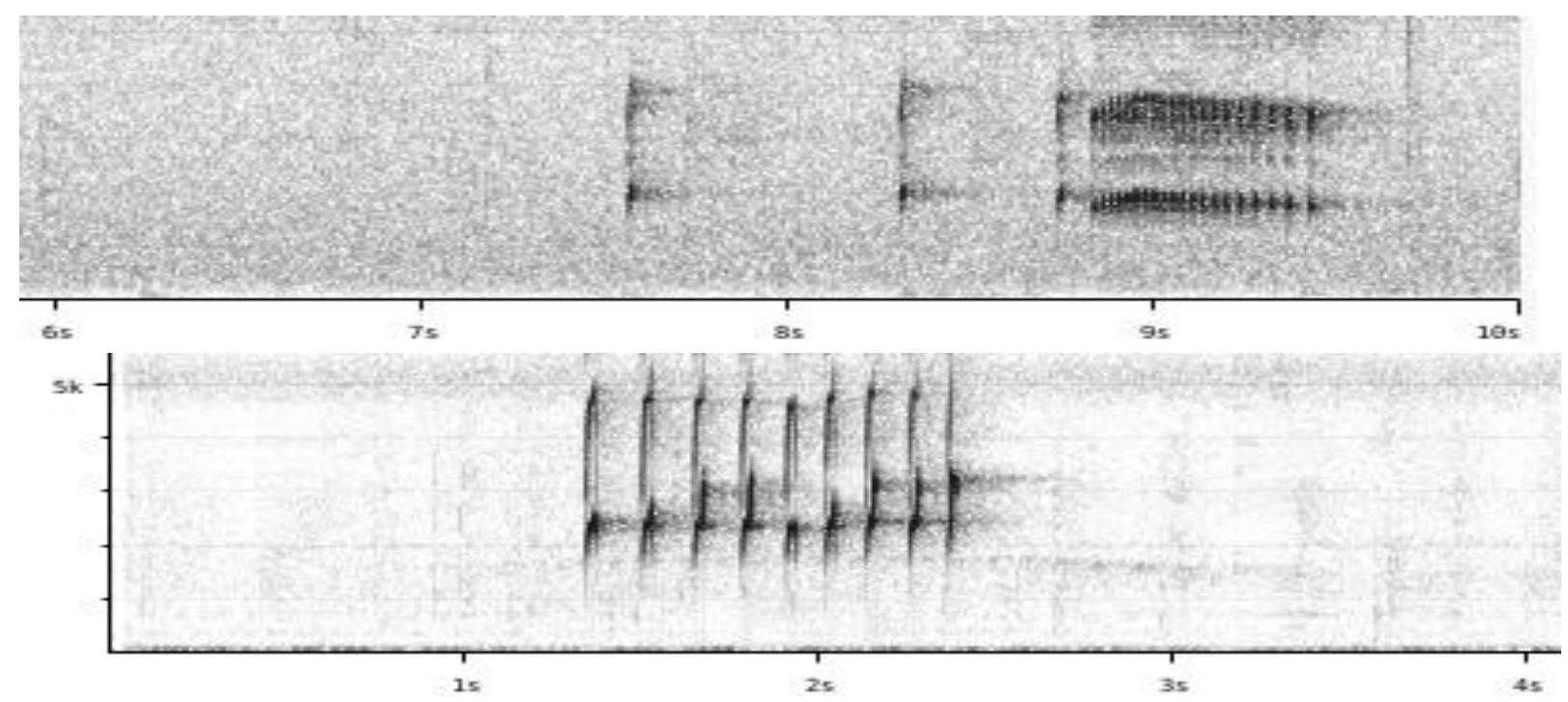

Figure 1: typical song East of the Rio Negro (top) and West of the Rio Negro (bottom)

Differences are clear by ear, and from the measurements we can deduct that birds west of the Rio Negro have a song with a lower number of notes (score 2-3), given at a slower pace (score 3-4), at a slightly higher average frequency (score 1-2) and notes have a longer duration (score 1-2). When applying Tobias criteria, this would result in a total vocal score of about 6 .

There are however a few recordings from Ecuador (XC61444 and XC16644) which are a series of notes delivered much faster than usual. This may be rather a call note, or of excited birds after playback. I measured the basic parameters for these unusual vocalizations:

total length

\# of notes

max. pace

av. freq.

max. note length
$0.77-1.14 \mathrm{~s}$

$15-20$

$0.036-0.070$

$2040-2250 \mathrm{~Hz}$

$0.040-0.056 \mathrm{~s}$

Av. freq., max. note length and also note shape are still as the 'normal' song, but pace and \# of notes are higher, and come close to Guianan birds (although still hardly any overlap). I consider these as not being homologous vocalizations, but if they were to be included in the overall comparison, than vocal score would be rather about 4. 

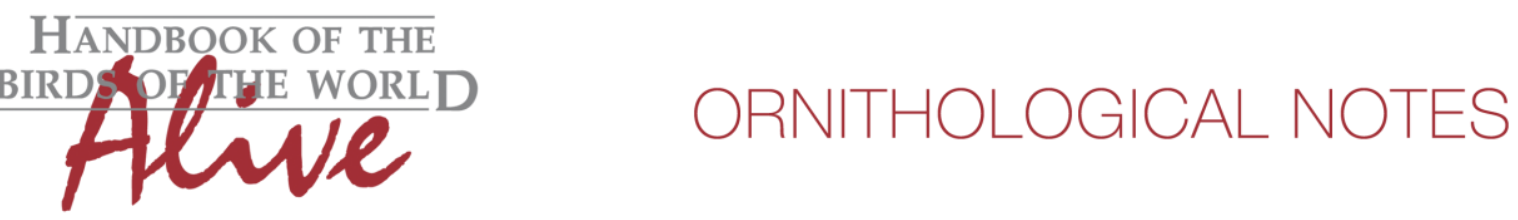

This note was finalized on 1st July 2015, using sound recordings available on-line at that moment. We would like to thank in particular the sound recordists who placed their recordings for this species on XC: Nick Athanas, Roger AhIman, Peter Boesman, Oswaldo Cortes, Sidnei Dantas, David Geale, Patrick Ingremeau, Ottavio Janni, Jon King, Niels Krabbe, Dan Lane, Gabriel Leite, Hans Matheve, John V Moore, Scott Olmstead, Alexandre Renaudier, Eduardo Schultz, Andrew Spencer, Joseph Tobias, Thiago Vernaschi Costa and Charlie Vogt.

\section{References}

Cohn-Haft, M., Whittaker, A., and Stouffer, P.C. (1997). A new look at the "species-poor" central Amazon: updates and corrections to the avifauna north of Manaus, Brazil. Pages 205235 in "Studies in Neotropical ornithology honoring Ted Parker"

Tobias, J.A., Seddon, N., Spottiswoode, C.N., Pilgrim, J.D., Fishpool, L.D.C. \& Collar, N.J. (2010). Quantitative criteria for species delimitation. Ibis 152(4): 724-746.

\section{Recommended citation}

Boesman, P. (2016). Notes on the vocalizations of White-eyed Tody-tyrant (Hemitriccus zosterops). HBW Alive Ornithological Note 124. In: Handbook of the Birds of the World Alive. Lynx Edicions, Barcelona. (retrieved from http://www.hbw.com/node/932047 on 5 August 2016). 